\title{
The Recovery of Fine Cassiterite from Metasedimentary
}

\section{Rock}

Ismail Ibrahim, Md Muzayin Alimon and Salmah Baharuddin

Mineral Research Centre, Minerals and Geoscience Department Malaysia, Jalan Sultan Azlan Shah, Ipoh 31400, Perak, Malaysia

\begin{abstract}
It is known that ore containing cassiterite $\left(\mathrm{SnO}_{2}\right)$ has been our most important source of tin since antiquity and its successful separation continuously pose problems to mineral processors. The situation is more pronounced since the depletion of the more easily recoverable alluvial reserves forces us to work with the more complex deposits such as hardrock cassiterite ores. In order to understand more about the challenges in processing complex tin ore deposits, a metasedimentary rock ore sample from a mine in Malaysia was used in this study. Chemical analysis by wet method shows that $\mathrm{SnO}_{2}$ content in the sample was $2.86 \%$, while for mineralogical analysis, the x-ray diffractogram (XRD) of the sample had identified that besides cassiterite, the sample also contained minerals such as quartz $\left(\mathrm{SiO}_{2}\right)$ and clinochlore. Furthermore, the FESEM (field emission scanning electron microscope) micrograph analysis carried out on a polish section of the sample indicated that the fine cassiterite particles (approximately $80 \mu \mathrm{m}$ ) were found to be disseminated in the quartz minerals. Prior to the separation processes, grindability studies were carried-out on crushed samples to liberate the cassiterite from other gangue minerals and at the same time, avoid producing high percentage of fines. For the separation of tin from gangue minerals on the ground samples, two stages of gravity separations by shaking tables were carried out. The first stage was run on ground samples and for the second stage, the middling product from the first stage was re-tabled. Magnetic separation process on Concentrate 1 (stage 1) and Concentrate 2 (stage 2) products from the shaking table increased the grade of $\mathrm{SnO}_{2}$ to $46.85 \%$ and $61.90 \%$ respectively (as a non-magnetic products). Further concentration process of these non-magnetic products by high tension separator, increased the grade of $\mathrm{SnO}_{2}$ from $85.05 \%$ to $98.77 \%$.
\end{abstract}

Key words: Fine cassiterite, grinding, shaking table, magnetic separation, high tension separation.

\section{Introduction}

Cassiterite, $\mathrm{SnO}_{2}$ is thus far the most important source of tin whereby its concentration and separation is one of the oldest processes, and has been known since antiquity [1]. It is often found in hydrothermal veins and pegmatite, but it also forms as a secondary processes in the oxidation zone of weathered tin deposits [2]. During erosion, cassiterite can be broken into nodules to large grains and concentrated in placer deposits. The nodules seem to be heavy and having a greasy luster. Cassiterite is very black and hence tests are sometimes essentials [2]. However, as we move to produce cassiterite concentrate from hardrock deposits where they exist in fine form, slime is produced during mineral processing. It is deposited along river banks or

Corresponding author: Ismail Ibrahim, Dr., research field: mineral processing. E-mail: is.ibrahim@jmg.gov.my. discharged into the tailing reservoirs which results in environmental problems. Some of the fine tin cannot be recovered by performing gravity, magnetic and high tension separations methods because of the limitation in controlling parameters [3].

Gravity separation processes such as by shaking table, can only perform effectively for ore at certain size ranges approximately between 105 to $600 \mu \mathrm{m}$ [4, 5]. At the processing plant, the comminution has to be carried out on the rock containing cassiterite in order to liberate the minerals and to enable its concentration by physical means $[4,6]$. However, as the liberation size may be below $105 \mu \mathrm{m}$ and given that the separation process of the shaking table, magnetic separator or high tension are only suitable for mineral separation in a relatively coarser size range, using the same methods for separation of fine cassiterite is quite challenging. Nevertheless Siqing Liu (2011) [7] stated that fine 
grinding needs to be conducted to get a high quality tin concentrate and a great loss of tin cannot be avoided when treating the ore by gravity concentration. Based on the above facts, a two-stage separation, with a low intensity magnetic separator and a shaking table were selected to test the ore.

This paper will discuss the grinding process performance using ball mill on the selected ore sample. It was found that 16 minutes grinding time was able to liberate some of the cassiterite from other gangue minerals without producing high percentage of fines. Sandy (2004) [8] suggests that maximising recovery is done by targeting recovery in a certain size fraction or fractions with the highest value mineral loading. In this study the $-600 \mu \mathrm{m}$ size range of sample was used for further separation tests. In the ground sample, $33.2 \%$ of $\mathrm{SnO}_{2}$ was distributed in the size range below $105 \mu \mathrm{m}$ (slime) and this fine material also has to be treated. The possibilities of using shaking table, magnetic separator and high tension to recover the fine cassiterite, was studied. The performance of each process was measured through the grade and recovery of $\mathrm{SnO}_{2}$.

\section{Materials and Methods}

\subsection{Sample Preparation and Characterization}

The metasedimentary rock samples used in this experimental works were obtained from Sungai Perlis Bed, Ulu Paka, Terengganu, Malaysia. This metasediment was mainly interbedded carbonaceous slate, argillite, phyllite and variably metamorphosed siltstone and sandstone, including some conglomerate, minor development of hornfels [9].

For sample preparation, the rock samples were crushed using jaw and cone crushers and mixed thoroughly, sample weighed approximately $3.260 \mathrm{~kg}$ was taken for further experimental tests. The crushed product was split to obtain $2 \mathrm{~kg}$ of head sample. Then it was sieved to pass through $600 \mu \mathrm{m}$. One kilogram of the oversize products was ground for 15 minutes for characterization tests. The ground sample was sieved and split to get suitable amount of sample (i) to determine $\mathrm{SnO}_{2}$ content by wet assay, (ii) to determine the chemical composition by X-ray fluorescence (XRF), (iii) to identify minerals by X-ray diffraction (XRD), (iv) to visualize the shape, size, texture and morphology of the particles by stereo zoom microscope and FESEM (field emission scanning electron microscope) and (v) to identify the elements in the sample by EDAX (energy dispersive analysis X-ray).

\subsection{Grindability Test}

Grindings of crushed materials were performed for $10,12,16,20,24$ and 28 minutes to achieve a particle size in which corresponds to the liberation of $\mathrm{SnO}_{2}$ and to avoid producing high percentage of fines. Dry grindings were carried out in a laboratory ball mill with a combination of $5.0 \mathrm{~cm}, 3.75 \mathrm{~cm}$ and $2.50 \mathrm{~cm}$ diameter steel balls at 65 RPM (revolutions per minute). The size distribution of each test was recorded and $\mathrm{d}_{80}$ plotted. For this study, the control size of feed material was below $600 \mu \mathrm{m}$ with selected grinding time. $\mathrm{SnO}_{2}$ content in the size fractions of $+600 \mu \mathrm{m},-600+425$ $\mu \mathrm{m},-425+212 \mu \mathrm{m},-212+105 \mu \mathrm{m}$ and $-105 \mu \mathrm{m}$ were determined using wet assay [6].

\subsection{Shaking Table Test}

For a pre-concentration of cassiterite, gravity separation by shaking table was carried out in two (2) stages (a) the first stage of comminuted ROM (run of mine) samples and (b) on a sample of middling resulting from the first stage of tabling. The dimensions of the shaking table were $75 \mathrm{~cm}$ long and $40 \mathrm{~cm}$ wide. Sieved materials $(-600 \mu \mathrm{m})$ from different batches were mixed together and fed into the shaking table. The middling from tabling was re-run by tabling. The parameters used for shaking table were (i) tilt slope angle: $2^{\circ}$; (ii) water flow rate: $120 \mathrm{~L} / \mathrm{hr}$; (iii) stroke length: $1.25 \mathrm{~cm}$; (iv) stroke frequency: 26 time/minute and (v) sample feed rate: $250 \mathrm{~g} /$ minute.

\subsection{Magnetic Separation Test}

The table concentrates and middling were then 
passed through the double disc magnetic separator to get rid of free iron. The parameters used for the experiment were (i) disc 1:800 Gauss and (ii) disc 2 : 1200 Gauss.

\subsection{High Tension Separation Test}

High tension separation test with the parameters of (i) voltage: $30 \mathrm{kV}$; (ii) rotor speed: $80 \mathrm{RPM}$; (iii) first electrode angle: $45^{\circ}$ and (iv) second electrode angle: $20^{\circ}$, was carried out for non-magnetic product from the magnetic separation test.

\subsection{Product Analyses}

All products of shaking table (concentrate, middling and tailing) and high tension separator (conductor, middling and non-conductor) were analyzed by wet assay to determine the percentage of Sn. The Fe content of magnetic and non-magnetic materials from the magnetic separation tests were also determined by wet assay. The conductor concentrate was examined by FESEM (field emission scanning electron microscope) and the percentages of elements present were estimated by EDX (energy dispersive X-ray).

\section{Results and Discussions}

\subsection{Characterization Test}

The content of $\mathrm{SnO}_{2}$ in ROM sample was $2.86 \%$. The chemical composition of the sample by XRF analysis showed the percentage of $\mathrm{SiO}_{2}(64.57 \%)$, $\mathrm{Al}_{2} \mathrm{O}_{3}$ (13.41\%), $\mathrm{Fe}_{2} \mathrm{O}_{3}$ (9.66\%), $\mathrm{MgO}$ (1.6\%), $\mathrm{SnO}_{2}$ (1.25\%), $\mathrm{TiO}_{2}(0.59 \%), \mathrm{CaO}(0.35 \%)$ and $\mathrm{MnO}$ $(0.21 \%)$. For mineralogical analysis, the XRD of the sample identified that the major minerals were cassiterite $\left(\mathrm{SnO}_{2}\right)$, quartz $\left(\mathrm{SiO}_{2}\right)$, clinochlore minerals as shown in Fig. 1.

Observation under zoom stereo microscope on the polish section of ROM sample clearly indicated that coarse particles of quartz were associated with iron bearing minerals. However fine $\mathrm{SnO}_{2}$ was not detected. The field emission scanning electron microscope (FESEM) micrograph of polish section sample indicated that the fine cassiterite particles (around 80 $\mu \mathrm{m})$ were found to be disseminated in the quartz mineral (as shown in Figs. 3(a)-3(b)).

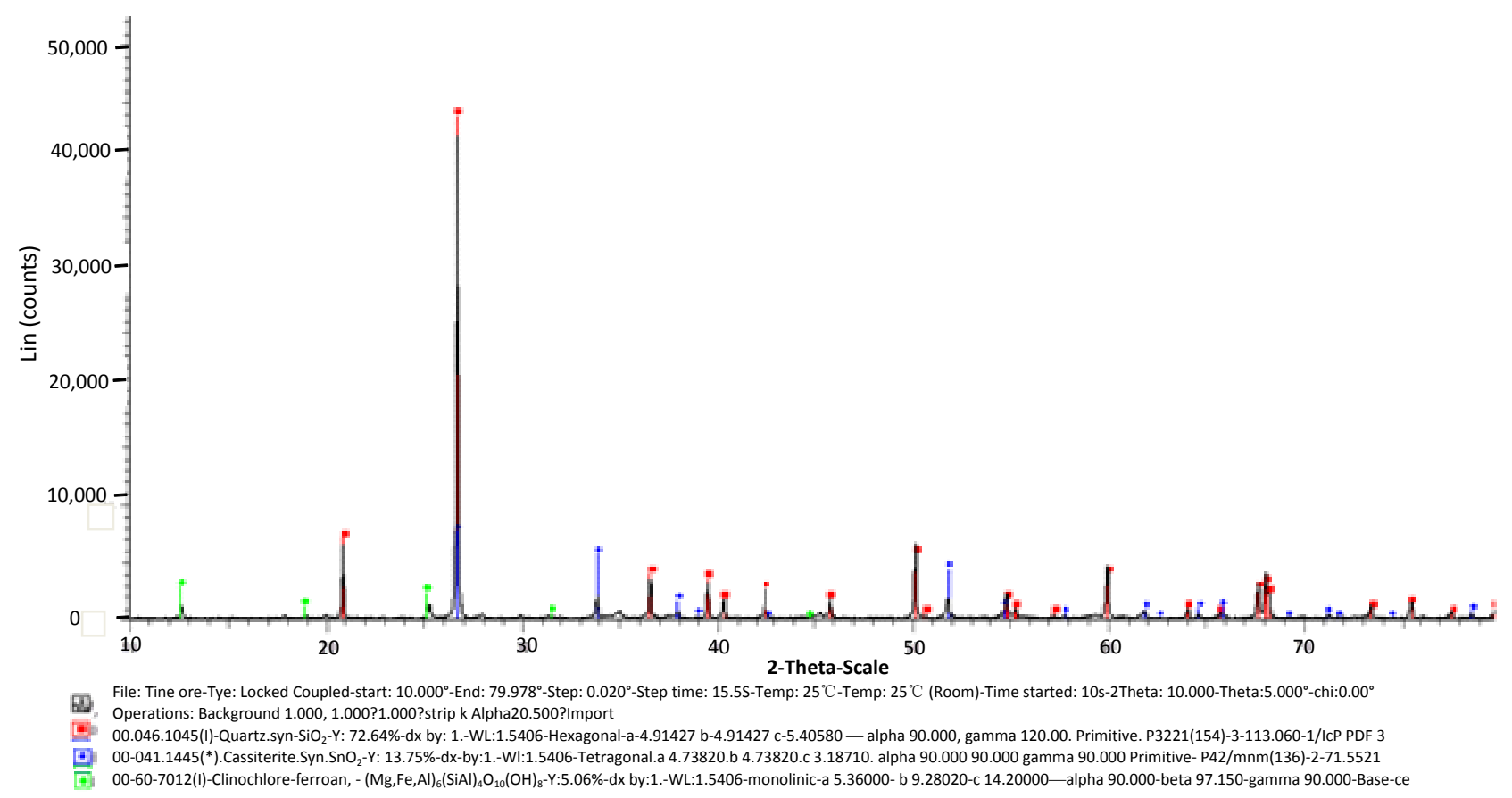

Fig. 1 XRD diffractogram has identified that the rock sample contains the major minerals of quartz $\left(\mathrm{SiO}_{2}\right)$, cassiterite $\left(\mathrm{SnO}_{2}\right)$ and clinochlore minerals. 


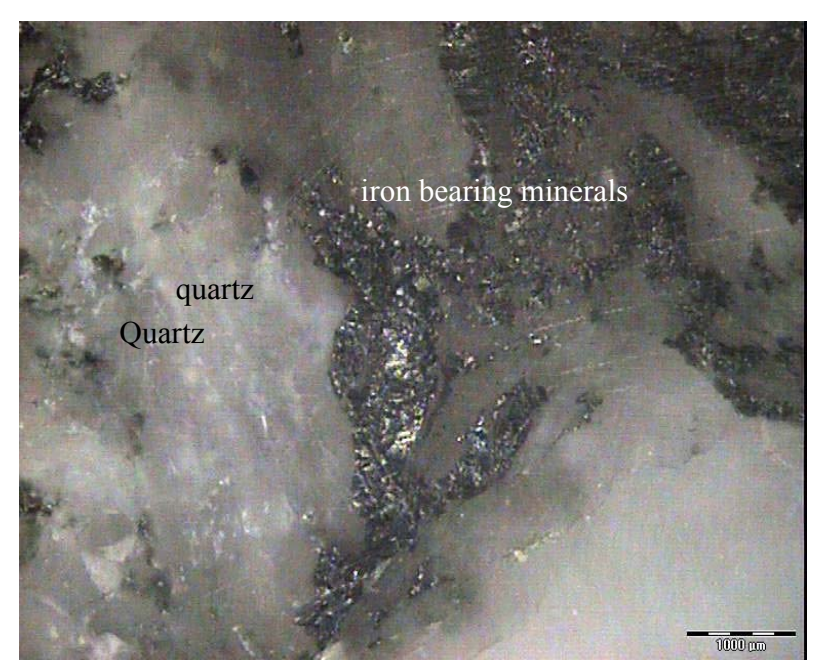

Fig. 2 Polish section of rock sample showing the quartz and iron bearing minerals.

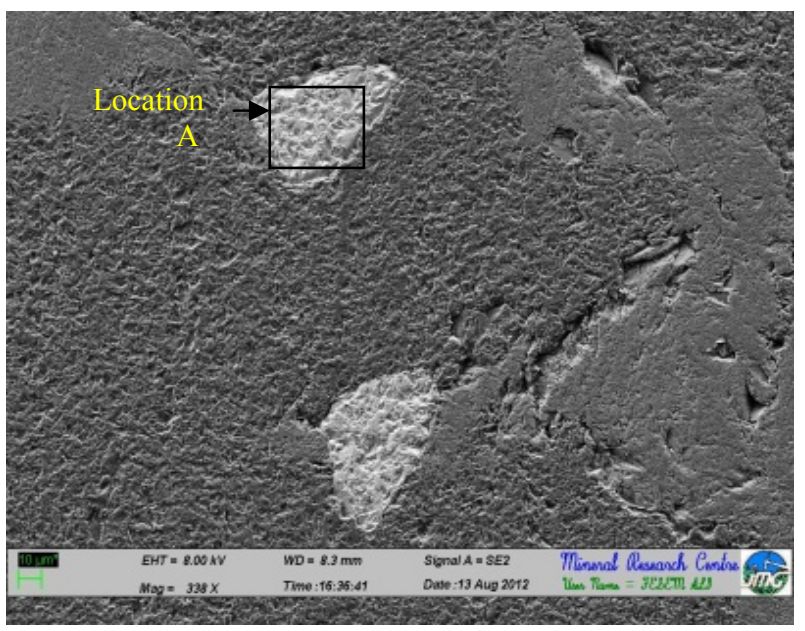

Fig. 3(a) FESEM analysis on polish section sample at Location A.

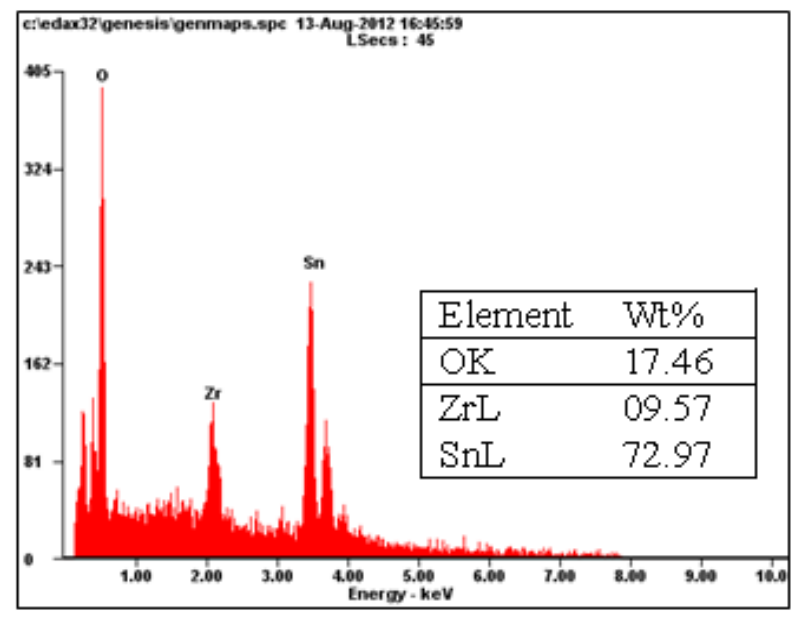

Fig. 3(b) EDAX analysis on polish section sample at Location $A$ in Fig. 3(a).

\subsection{Grindability Tests}

Size distribution of particles is shown in Fig. 4(a) was reported as cumulative percentage passing in the size range $8,000 \mu \mathrm{m}$ to $105 \mu \mathrm{m}$. For grinding periods of 10 minutes, 12 minutes, 16 minutes, 20 minutes, 24 minutes and 28 minutes with the $d_{80}$ values were 4,350 $\mu \mathrm{m}, 4,110 \mu \mathrm{m}, 3,400 \mu \mathrm{m}, 3,000 \mu \mathrm{m}, 2,500 \mu \mathrm{m}$ and $1,550 \mu \mathrm{m}$ respectively. Initially grinding for 16 minutes was considerable appropriate time period to liberate the cassiterite from other gangue minerals without producing fine particles. Sn distribution in various fractions of $-800+600 \mu \mathrm{m},-600+425 \mu \mathrm{m}$, $-425+212 \mu \mathrm{m},-212+105 \mu \mathrm{m}$ and $-105 \mu \mathrm{m}$ is shown in Fig. 4(b). For grinding periods of 10 minutes and 12 minutes, there were more than $48 \%$ of $\mathrm{Sn}$ present in the size range between $600 \mu \mathrm{m}$ and $800 \mu \mathrm{m}$, whereas for the grinding periods of 20 minutes, 24 minutes and 28 minutes, it was found that more than $30 \%$ of Sn was below $105 \mu \mathrm{m}$. The ideal grinding time was 16 minutes because the minimal percentage of Sn that was below $105 \mu \mathrm{m}$ and above $600 \mu \mathrm{m}$ was approximately $25 \%$. Moreover, for Sn distribution at 16 minutes grinding time, the size fractions of $-600+$ $425 \mu \mathrm{m},-425+212 \mu \mathrm{m},-212+105 \mu \mathrm{m}$ and $-105 \mu \mathrm{m}$ were determined to be $13.34 \%, 29.05 \%, 24.41 \%$ and $33.2 \%$ respectively as shown in Table 1 and Fig. 4(c). Since the percentage of Sn distribution in $-105 \mu \mathrm{m}$ was $33.2 \%$, it should be collected as much as possible.

\subsection{Tabling}

The separation results of $\mathrm{SnO}_{2}$ for the 16 minutes ground sample by shaking table showed that the $\mathrm{SnO}_{2}$ in Concentrate 1 was $64.21 \%$ which resulted in the distribution of $\mathrm{SnO}_{2}$ to be $49.80 \%$ (Table 2). Since the grade of $\mathrm{SnO}_{2}$ in Middling 1 was only $3.75 \%$, the middling material was re-tabled to produce $38.09 \%$ $\mathrm{SnO}_{2}$ in Concentrate 2.1 as shown in Table 3.

\subsection{Magnetic Separations}

The results of the magnetic separation process are 


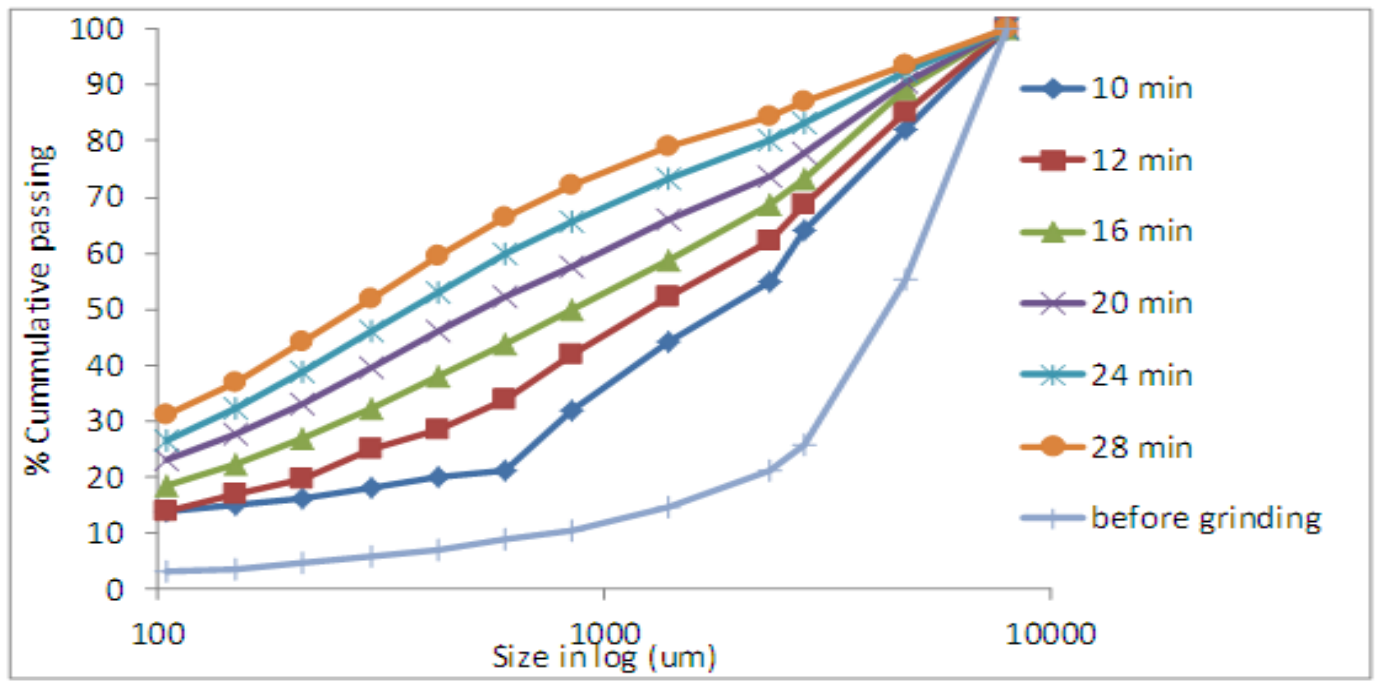

Fig. 4(a) Particle size distribution at different grinding time.

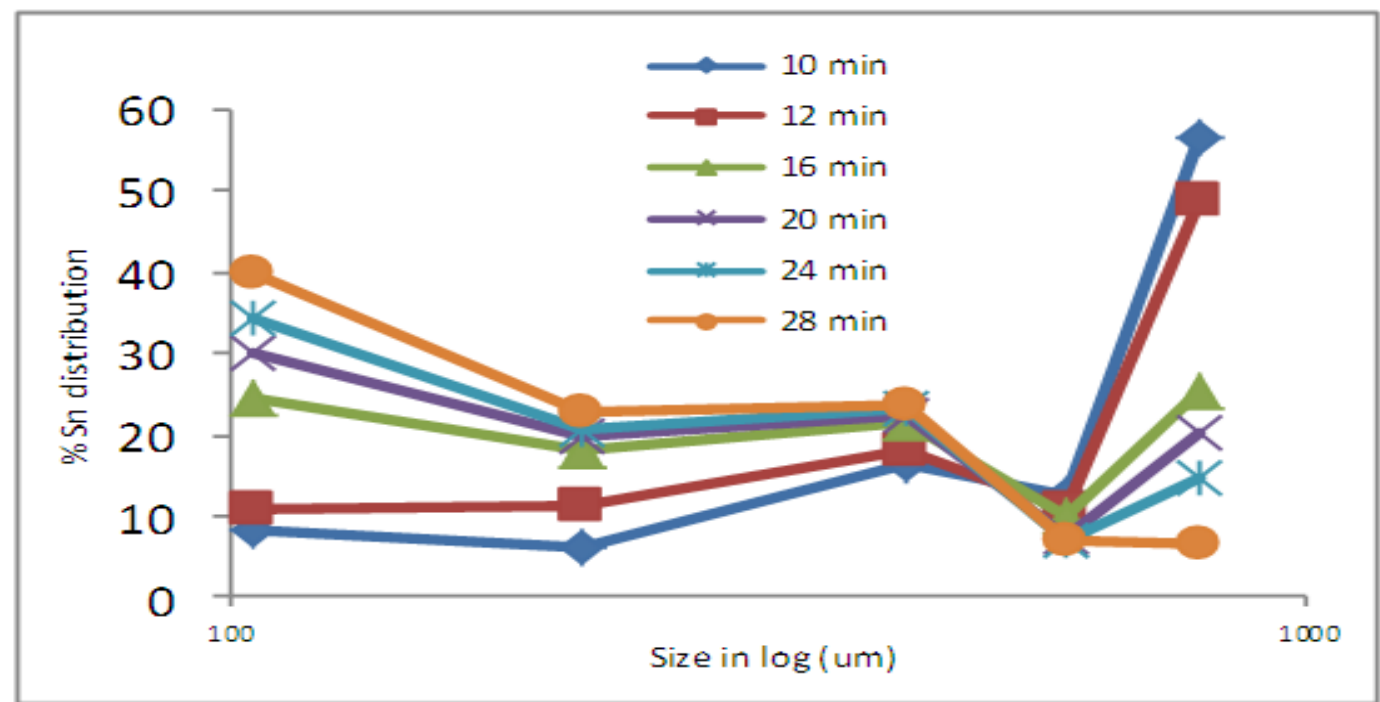

Fig. 4(b) Sn distribution in various size fraction.

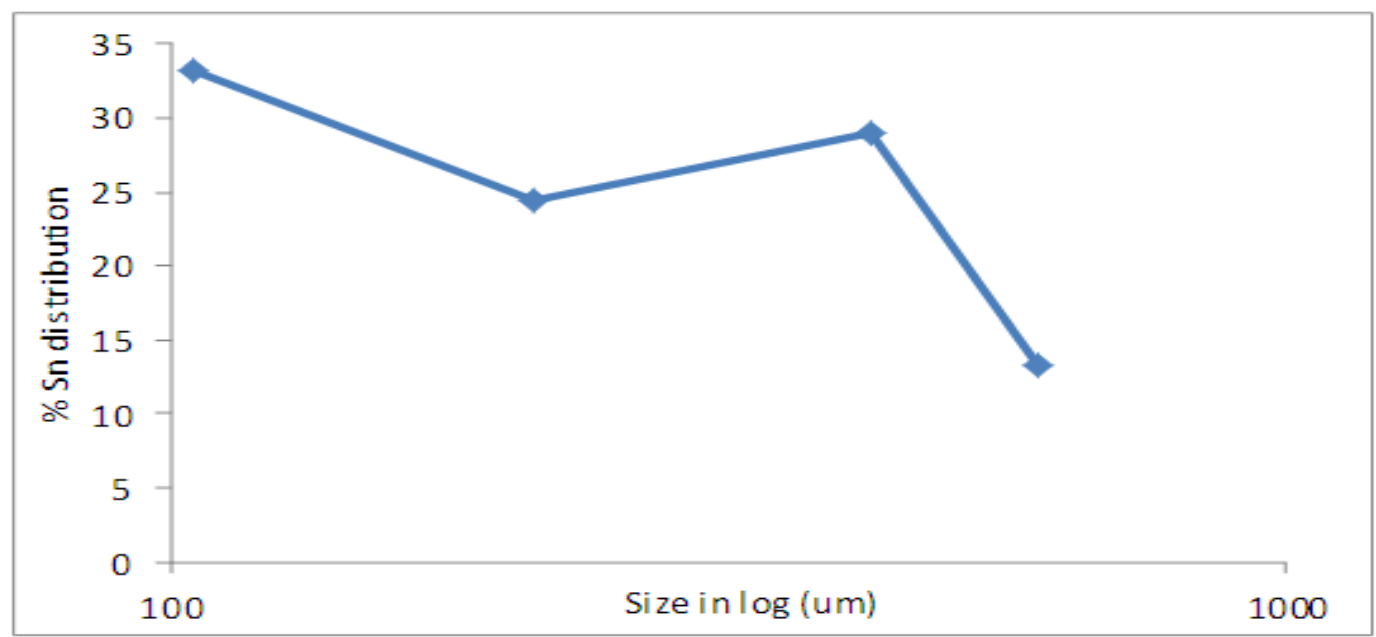

Fig. 4(c) Sn distribution in various size ranges for the 16 minutes ground sample. 
Table 1 Sn distribution in various size fraction.

\begin{tabular}{ll}
\hline Size $(\mu \mathrm{m})$ & $\%$ Sn distribution \\
\hline$-600+425$ & 13.34 \\
$-425+212$ & 29.05 \\
$-212+105$ & 24.41 \\
-105 & 33.2 \\
\hline
\end{tabular}

Table 2 The results of stage 1 tabling products for $-600 \mu \mathrm{m}$ fraction.

\begin{tabular}{lcccc}
\hline Sample & Weight (\%) & $\mathrm{Sn}(\%)$ & $\mathrm{SnO}_{2}(\%)$ & ${\text { Dist. of } \mathrm{SnO}_{2}(\%)}$ \\
\hline Concentrate 1 & 4.48 & 50.58 & 64.21 & 49.80 \\
Middling 1 & 69.14 & 2.95 & 3.75 & 44.80 \\
Tailing 1 & 26.38 & 0.93 & 1.18 & 5.40 \\
\hline
\end{tabular}

Table 3 The results of stage 2 tabling products for middling obtained from stage 1.

\begin{tabular}{|c|c|c|c|c|}
\hline Sample & Weight ( \%) & $\operatorname{Sn}(\%)$ & $\mathrm{SnO}_{2}(\%)$ & Dist. of $\mathrm{SnO}_{2}(\%)$ \\
\hline Concentrate 2.1 & 1.50 & 30.00 & 38.09 & 27.25 \\
\hline Concentrate 2.2 & 14.00 & 5.10 & 6.47 & 43.19 \\
\hline Middling 2.1 & 66.40 & 0.65 & 0.83 & 26.28 \\
\hline Tailing 2.1 & 18.10 & 0.30 & 0.38 & 3.28 \\
\hline
\end{tabular}

Table 4 The results of magnetic separation products for magnetic and non-magnetic by DDMS.

\begin{tabular}{llllll}
\hline Test/Sample & Product & Weight (\%) & $\mathrm{Sn}(\%)$ & $\mathrm{SnO}_{2}(\%)$ & $\mathrm{Dist} \mathrm{SnO}_{2}(\%)$ \\
\hline Test M1/ & Magnetic1 & 32.10 & 22.34 & 28.36 & 17.81 \\
Concentrate 1 & Non magnetic1 & 67.90 & 48.76 & 61.9 & 82.19 \\
Test M2/ & Magnetic 2.1 & 39.70 & 21.20 & 26.91 & 27.42 \\
Concentrate 2.1 & Non magnetic 2.1 & 60.30 & 36.90 & 46.85 & 72.58 \\
Test M3/ & Magnetic 3 & 46.27 & 1.45 & 1.84 & 16.31 \\
Concentrate 2.2 & Non magnetic 3 & 53.73 & 6.40 & 8.13 & 83.69 \\
Test M4/Midd2.1 & Magnetic 4 & 46.73 & 0.47 & 0.60 & 34.26 \\
& Non magnetic 4 & 53.27 & 0.80 & 1.01 & 65.74 \\
\hline
\end{tabular}

shown in Table 4. It shows that the grade of $\mathrm{SnO}_{2}$ for non-magnetic products represented by Non-magnetic 2.1 and Non-magnetic 1 have increased $\mathrm{SnO}_{2}$ to $46.85 \%$ and $61.90 \%$ respectively. Thus resulting in the distribution of $\mathrm{SnO}_{2}$ to $72.58 \%$ of $\mathrm{SnO}_{2}$ (Non-magnetic 2.1 ) and $82.19 \%$ (Non-magnetic 1). However, both non-magnetic products from tests M3 and M4 showed very low grade of $\mathrm{SnO}_{2}$. This is due to the feed samples were originated from Concentrate 2.2 and Middling 2.1 from stage 2 of tabling process which already contained $6.47 \%$ and $0.83 \% \mathrm{SnO}_{2}$ respectively.

\subsection{High Tension Separation}

Table 5 shows the concentration process of $\mathrm{SnO}_{2}$ for non-magnetic products by high tension separator. It can be seen that for samples H/Tension 1 and H/Tension 2, the grade of $\mathrm{SnO}_{2}$ for conductor and middling were between $89.25 \%$ and $98.77 \%$, while distribution of $\mathrm{SnO}_{2}$ (conductor + middling) were more than $80 \%$. The grade of $\mathrm{SnO}_{2}$ for $\mathrm{H} /$ Tension 3 showed only the conductor (Conductor 3 ) giving high grade of $\mathrm{SnO}_{2}$ of $85.05 \%$ and its $\mathrm{SnO}_{2}$ distribution was $52.28 \%$. However the grade of $\mathrm{SnO}_{2}$ in middling (Middling 3) was only $55.23 \%$, hence there was a need to re-run through the high tension separator. Nevertheless, FESEM and EDAX analyses for micrographs particles in the Conductor 1 sample are shown in Fig. 5(a) to Fig. 5(e). EDAX analyses were performed to identify the percentage of elements present in the sample. Micrographs of particles for Conductor 1 are shown in Fig. 5(a) as indicated by Locations A to D.

Table 6 shows the overall percentage of elements for 
Conductor 1 based from Figs. 5(b)-5(e). It can be seen from Figs. 5(b)-5(d) that high $\mathrm{Sn}$ contents were obtained from Location A $(60.78 \%)$, Location B (68.29\%) and Location C (66.96\%). Sn content from Location D was only $20.71 \%$ (Fig. 5(e)), due to major association with iron bearing minerals as evidenced by Fe content of $25.03 \%$.

\subsection{Overall $\mathrm{SnO}_{2}$ Distribution}

It seemed that the overall $\mathrm{SnO}_{2}$ with its grade more than $85 \%$ after passing through high tension separation process was recovered approximately by $46.01 \%$ (shown in Table 7) from the initial weight 3,260 $\mathrm{g}$ of feed sample. It was found that only those liberated and coarser $\mathrm{SnO}_{2}$ particles were able to be separated from their gangue minerals. The rest of $\mathrm{SnO}_{2}$ were expected very fine and locked in their host minerals (iron bearing) as reporting in the products of table tailing $(9.64 \%)$ and

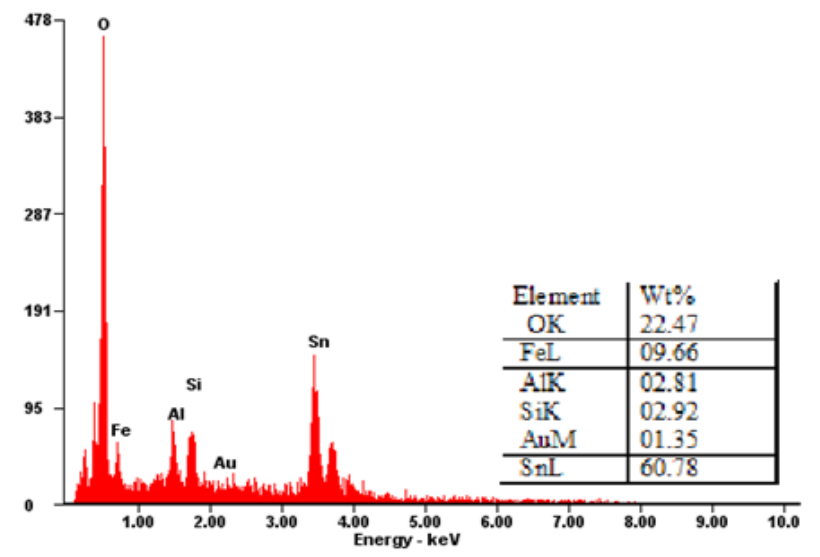

Fig. 5(b) EDAX spectrum at Location A in Fig. 5(a).

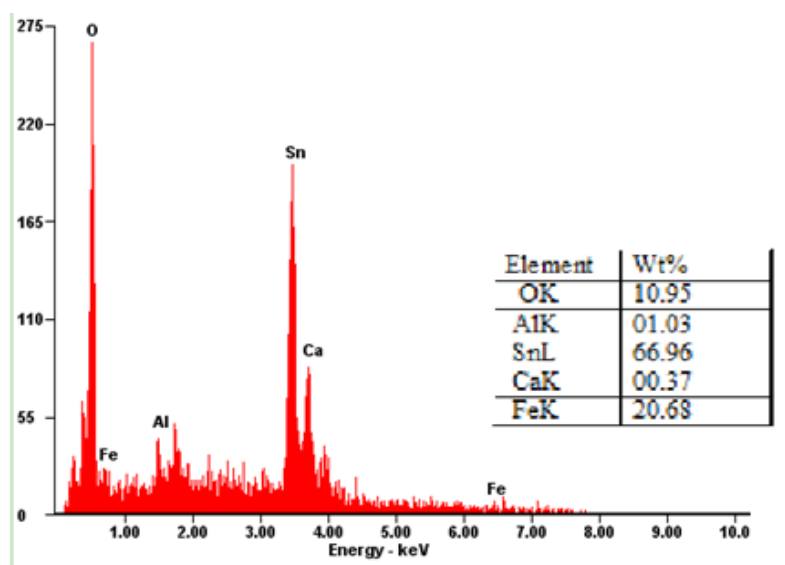

Fig. 5(d) EDAX spectrum at Location C in Fig. 5(a). magnetic materials $(23.53 \%)$. The locked $\mathrm{SnO}_{2}$ with iron bearing can be conceived by Fig. 5(a) at Location D which shows only $20.21 \%$ Sn content, but $\mathrm{Fe}$ was $25.03 \%$ (Fig. 5(e)).

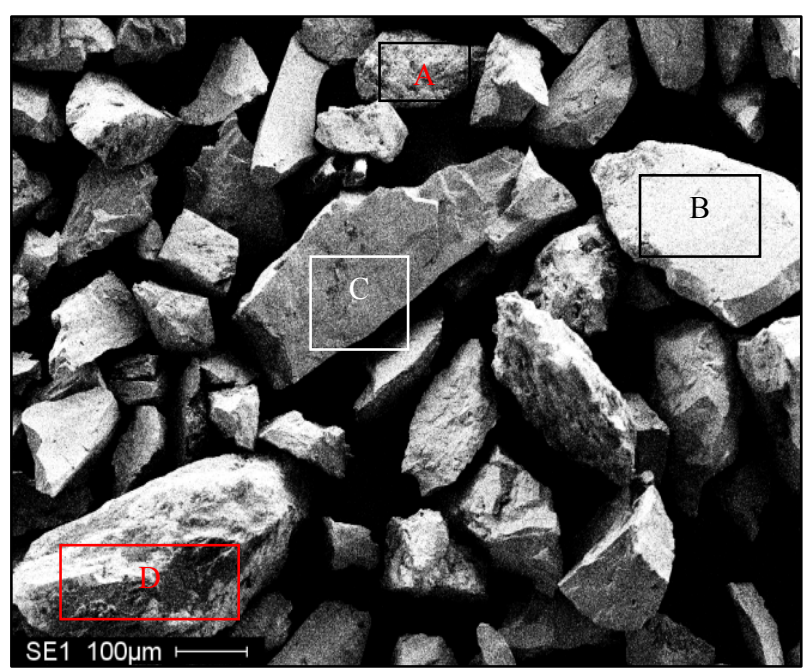

Fig. 5(a) FESEM micrograph shows the presence of $\mathrm{SnO}_{2}$ at locations A to D for sample Conductor 1.

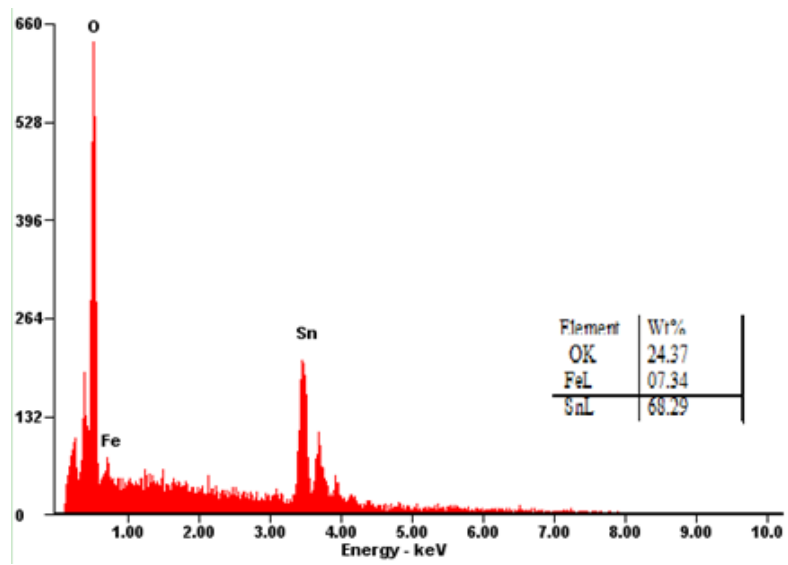

Fig. 5(c) EDAX spectrum at Location B in Fig. 5(a).

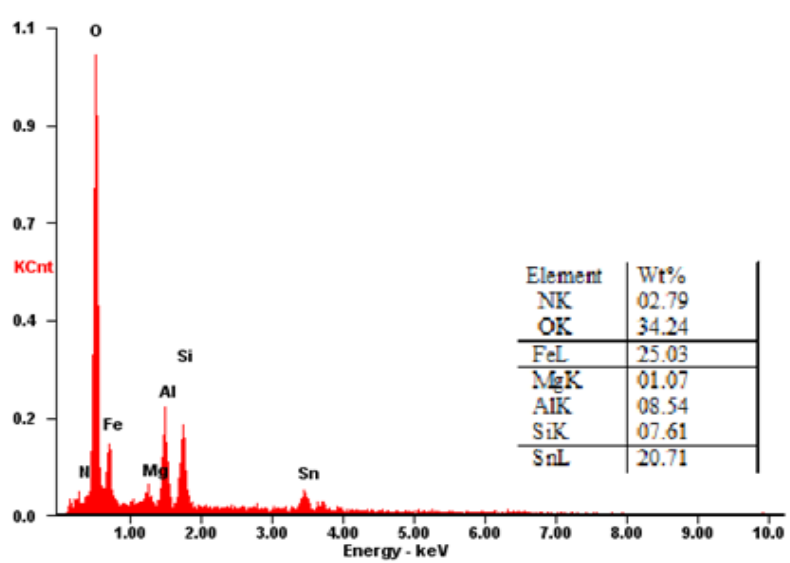

Fig. 5(e) EDAX spectrum at Location D in Fig. 5(a). 
Table 5 The results of high tension separation products for conductor, middling and non-conductor.

\begin{tabular}{llllll}
\hline Test/Sample & Products & Weight (\%) & $\mathrm{Sn}(\%)$ & $\mathrm{SnO}_{2}(\%)$ & Dist. of SnO $_{2}(\%)$ \\
\hline \multirow{2}{*}{ H/Tension 1 } & Conductor 1 & 33.40 & 75.70 & 96.11 & 46.90 \\
Non-Magnetic 1 & Middling 1 & 24.90 & 77.80 & 98.77 & 35.93 \\
& Non-Conductor 1 & 41.70 & 22.20 & 28.18 & 17.17 \\
\hline \multirow{2}{*}{ H/Tension 2 } & Conductor 2 & 28.80 & 74.30 & 94.33 & 51.52 \\
Non-Magnetic 2 & Middling 2 & 19.40 & 70.30 & 89.25 & 32.83 \\
& Non-Conductor 2 & 51.80 & 12.55 & 15.93 & 15.65 \\
\hline \multirow{2}{*}{ H/Tension 3 } & Conductor 3 & 5.50 & 66.60 & 85.05 & 52.28 \\
Non-Magnetic 3 & Middling 3 & 4.80 & 43.50 & 55.23 & 29.80 \\
& Non-Conductor 3 & 89.70 & 1.40 & 1.78 & 17.92 \\
\hline \multirow{2}{*}{ H/tension 4 } & Conductor 4 & 0.20 & 41.80 & 53.07 & 8.65 \\
Non-Magnetic 4 & Middling 4 & 1.80 & 5.50 & 6.98 & 10.24 \\
\hline
\end{tabular}

Table 6 The overall percentage of elements for Conductor 1 based from Figs. 5(b)-5(e).

\begin{tabular}{lllll}
\hline \multirow{2}{*}{ Elements } & \multicolumn{4}{c}{ Conductor 1 } \\
\cline { 2 - 5 } & Location A & Location B & Location C & Location D \\
\hline $\mathrm{O}$ & 22.47 & 24.37 & 10.95 & 34.24 \\
$\mathrm{Fe}$ & 9.66 & 7.34 & 20.68 & 25.03 \\
$\mathrm{Al}$ & 2.81 & - & 1.03 & 8.54 \\
$\mathrm{Si}$ & 2.92 & - & - & 7.61 \\
$\mathrm{Au}$ & 1.35 & 68.29 & - & - \\
$\mathrm{Sn}$ & 60.78 & 66.96 & 20.71 \\
\hline
\end{tabular}

Table 7 The results of products for tabling (tailing), magnetic separation (magnetic materials) and high tension separation (conductor, middling and non-conductor).

\begin{tabular}{llc}
\hline Test & Product & $\mathrm{SnO}_{2}(\%)$ \\
\hline Tabling & Tailing & 9.64 \\
Magnetic separation & Magnetic materials & 23.53 \\
High tension separation & Grade $\mathrm{SnO}_{2}>85 \%$ & 46.01 \\
& Grade $\mathrm{SnO}_{2}, 50 \%-85 \%$ & 3.86 \\
& Grade $\mathrm{SnO}_{2}<50 \%$ & 16.96 \\
& Total & 100.00 \\
\hline
\end{tabular}

\section{Conclusion}

Fine cassiterite particles, approximately $80 \mu \mathrm{m}$, were found to be disseminated in the quartz minerals in the metasedimentary rocks. Grinding for 16 minutes of the crushed ROM samples would be able to release some of the $\mathrm{SnO}_{2}$ from the host minerals and to prevent the formation of excessive slimes. For pre-concentration of cassiterite, gravity separation by shaking table should be carried out in two stages: first stage tabling of comminuted ROM samples and re-tabling of the middling from the first stage tabling.
Magnetic separation process on products from table Concentrate 1 (stage 1) and Concentrate 2 (stage 2) increased $\mathrm{SnO}_{2}$ recovery by $46.85 \%$ and $61.90 \%$ respectively as non-magnetic products. High tension separation of non-magnetic products from the magnetic separation process significantly increased the $\mathrm{SnO}_{2}$ grade from $85.05 \%$ to $98.77 \% \mathrm{SnO}_{2}$ which gave percentage recoveries of $82.08 \%$ to $84.35 \%$ (as conductor + middling products). However, the final recovery of high tension products having $\mathrm{SnO}_{2}$ grade more than $85 \%$ from the initial weight $3260 \mathrm{~g}$ of feed sample was approximately $46.01 \%$. This was due to the 
rest of $\mathrm{SnO}_{2}$ were expected very fine and locked in their host minerals (iron bearing) as reporting in the products of table tailing $(9.64 \%)$ and magnetic materials (23.53\%). Several experimental works can be extended on 20-28 minutes ground samples by physical separation for particles size above $100 \mu \mathrm{m}$. However for particles below $100 \mu \mathrm{m}, \mathrm{SnO}_{2}$ are suggested to be recovered using multi-gravity separator or enhancing through fine flotation of cassiterite.

\section{Acknowledgements}

The authors would like to thank and acknowledge the support of the Director of Mineral Research Centre, Minerals and Geoscience Department Malaysia and fellow staff of the Centre especially to the staff of Mineral Processing Technology Section for their assistance in this research. Thank is also due to the Minerals and Geoscience Department Malaysia, Terengganu in providing geological information and assistance in field trips.

\section{References}

[1] Gunther, H. M. 1981. "Mineralogical Investigations of Complex Tin Ores-A Contribution to Separation Problems, Comples Tin Ores and Related Problem." In Proceedings of the Seminar Organised in Collaboration, 5.
[2] Abubakre, O. K., Sule, Y. O., and Muriana, R. A. 2009. "Exploring the Potentials of Tailings of Bukuru Cassiterite Production of Iron Ore Pellets." Journal of Minerals \& Materials Characterization \& Engineering 8 (5): 359-66.

[3] Zhuoyue, L., Yongcheng, Z., and Xiong, T. 2013. "Recovery of Fine Cassiterite from Tin Tailings Slime by Froth Flotation." Advance Materials Research 634-638: 3478-83. (Trans Tech Publication, Switzerland)

[4] Ismail, I., Md Muzayin, A., and Salmah, B. 2011. Sulfide Mineral Separation Study from Rahman Hydraulic Tin Bhd Mine. Ipoh: Mineral Research Centre.

[5] Md Muzayin, A., and Nazwin, A. 2001. Preliminary Process for Upgrading Wolframit and Cassiterite Content from Sg Ayam Mine Sample, Kemaman Terengganu. Ipoh: Mineral Research Centre.

[6] Md Muzayin, A., Ismail, I., and Salmah, B. 2012. Characterization Study on Mineral Liberation and Cassiterite Concentration Processes for Complex Ore Samples from Induk Timur Tin Mine, Kemaman, Terengganu Darul Iman. Ipoh: Mineral Research Centre.

[7] Siqing, L., Ye, C., Xiong, T., and Peng, L. 2011. "Beneficiation of a Fine-sized Cassiterite Bearing Magnetite Ore." Journal of Minerals \& Metallurgical Processing 28 (2): 88-93.

[8] Sandy, A. H. 2004. "Feed Preparation for Gravity Separation in Grinding Circuits." Presented in the Gravity' 04, Perth, Australia.

[9] Zhuoyue, L., Yongcheng, Z., and Xiong, T. 2013. "Recovery of Fine Cassiterite from Tin Tailings Slime by Froth Flotation." Advance Materials Research 634-638: 3478-83. (Trans Tech Publication, Switzerland) 